\title{
PENGEMBANGAN SISTEM INFORMASI AKUNTANSI \\ PT. SURYA WARFA KHARISMA \\ STUDI KASUS: PENJULAN, PIUTANG, DAN PENERIMAAN KAS
}

\author{
Suparto Darudiato; Effie Cendana Sari
}

\author{
Jurusan Sistem Informasi, Fakultas Ilmu Komputer, Universitas Bina Nusantara \\ Jln KH Syahdan No. 9. Palmerah. Jakarta-11480 \\ supartod@binus.edu
}

\begin{abstract}
To increase sales, the management and sales department requires accurate, relevant and up-to-date information to support its function. Currently the amount of outstanding accounts receivables becomes one of the obstacles. So, credit limits criteria are applied as one of the effort to emphasis the outstanding receivables. Surely it will have an impact on increasing the effectiveness and efficiency of operations and ultimately will enhance the competitiveness. This research was done in three stages, data collection, analyzing the system requirements of current system to synergy with company's target, and the results of needs analysis are developed into a new accounting information system with object-oriented approach and UML diagrams.
\end{abstract}

Keywords: analysis, design, accounting information systems, sales, accounts receivables, cash receipts

\begin{abstract}
ABSTRAK
Dalam upaya meningkatkan penjualan, pihak manajemen memerlukan informasi yang akurat, relevan dan diperoleh dengan secara tepat waktu guna menunjang fungsinya. Saat ini terdapat beberapa kendala yang cukup mengganggu, diantaranya besarnya piutang yang belum cair pada waktunya, sehingga diterapkan penentuan kreteria limit kredit untuk menekan piutang yang tidak tertagih. Hal ini tentunya akan berdampak pada peningkatan efektifitas serta efisiensi operasional perusahaan dan pada akhirnya meningkatkan daya saing kompetitif. Penelitian ini dilakukan dengan tiga tahap, yaitu pengumpulan data dan analisis kebutuhan sistem melalui analisis sistem berjalan yang di-map dengan sasaran perusahan, dan dari hasil analisis kebutuhan, dikembangkan sistem informasi akuntasi yang baru dengan pendekatan berorientasi object dan diagram UML.
\end{abstract}

Kata kunci: analisis, perancangan, sistem informasi akunting, penjualan, piutang, penerimaan kas 


\section{PENDAHULUAN}

Dengan globalisasi dewasa ini, menyebabkan persaingan antar perusahaan semakin ketat. Perusahaan dituntut untuk memberikan pelayanan terbaik agar dapat meningkatkan kepuasan dan loyalitas pelanggan kepada perusahaan. Oleh karena itu, perusahaan harus mempertimbangkan strategi yang tepat untuk diterapkan dalam menghadapi segala tantangan tersebut.

Kebutuhan manajemen yang baik dan profesional, serta dapat diandalkan sangat diperlukan perusahaan untuk terus berkembang guna meningkatkan kinerja serta daya saing perusahaan. Pihak manajemen membutuhkan suatu informasi yang relevan, akurat, dan tepat waktu sehingga dapat berpikir kritis dan bertindak secara cepat.

Pada perusahaan dagang, transaksi penjualan, piutang dagang, dan penerimaan kas membentuk suatu rangkaian prosedur yang saling berkaitan erat. Selain itu, rangkaian kegiatan ini merupakan hal yang kritikal bagi perusahaan karena merupakan pusat bisnis dan penerimaan pendapatan terbesar yang diperoleh. Pengendalian intern dalam siklus penjualan dan pembelian barang mempunyai peranan yang cukup besar. Oleh karena itu, perancangan, pelaksanaan serta evaluasi yang berkelanjutan perlu dilakukan oleh perusahaan.

PT. Surya Warfa Kharisma merupakan perusahaan yang bergerak di bidang utama trading alat-alat listrik, dan suku cadang mesin. Sistem yang berjalan saat ini masih bersifat manual, dan sistem serta prosedur berjalan saat ini memungkinkan banyaknya terjadi kesalahan, terutama human error. Sebagian besar penjualan yang dilakukan kepada pelanggan tidak didahului dengan analisis kemampuan kredit pelanggan, sehingga menyebabkan saldo piutang perusahaan menjadi besar, sebagaimana bisa ditunjukkan dengan data historis. Hal ini tentunya menghambat pendapatan perusahaan yang masuk dan apabila dibiarkan terus menerus dapat menimbulkan kerugian. Selain itu, ketika proses penjurnalan dan pencatatan akuntansi, sering ditemukan kesalahan penulisan yang berdampak pada kesalahpahaman informasi akuntansi dan teridentifikasi ketika membandingan beberapa dokumen yang berkaitan.

Banyaknya transaksi penjualan, piutang, dan penerimaan kas yang tidak didukung oleh sistem terintegrasi dapat menimbulkan beberapa masalah pengendalian internal yang berkaitan dengan penyediaan informasi, pencatatan dan pengontrolan pada prosesnya. Untuk menghindari adanya penyimpangan dan penyampaian informasi yang keliru, maka sistem dan prosedur berkaitan harus dikelola secara tepat agar tidak menyebabkan pengambilan keputusan yang keliru. Dengan adanya sistem dan prosedur yang terintegrasi, kegiatan operasional perusahaan khususnya penjualan, piutang, dan penerimaan kas perusahaan dapat dilakukan dengan tepat waktu, akurat, dan lebih baik.

Mengingat makin berkembangnya perusahaan ini, kebutuhan dukungan sistem informasi akuntansi (SIA) yang terintegrasi dan pengendalian internal yang tepat diharapkan mampu mengendalikan transaksi penjualan, piutang, dan penerimaan kas yang efektif sehingga dapat meningkatkan kinerja dan efisiensi perusahaan.

\section{Tinjauan Pustaka}

Perkembangan perusahaan merupakan sebuah hal yang selalu menjadi tujuan dari pelaku bisnis. Untuk mengembangkan penjualan, tidaklah semata-mata hanya didukung oleh aktifitas fisik saja. Tetapi perlu ditunjang dengan administrasi yang baik dan rapi. SIA merupakan bagian dari sistem informasi manajemen yang khusus menyediakan informasi tentang akuntansi dan keuangan perusahaan. Seperti yang diungkapkan oleh Romney \& Steinbart (2006), SIA adalah suatu sistem yang 
mengumpulkan, mencatat, menyimpan, dan memproses data sehingga menghasilkan informasi kepada para pengambil keputusan.

Untuk mendukung fungsi sehari-hari dalam perusahaan, seorang manajer membutuhkan informasi yang akurat dan tepat waktu sebagai dasar dalam melakukan pengendalian dan perencanaan serta mendukung pengambilan keputusan. Menurut Romney \& Steinbart (2006), tujuan SIA adalah: (1)Mengumpulkan dan menyimpan data tentang aktivitas-aktivitas, sumber-sumber daya, dan para personil; (2)Mengubah data menjadi informasi yang berguna untuk membuat keputusan yang memungkinkan manajemen untuk merencanakan, melaksanakan, dan menilai aktivitas-aktivitas, sumber-sumber daya, dan para personil;(3)Menyediakan pengendalian yang memadai untuk melindungi aktiva organisasi, termasuk datanya, untuk memastikan bahwa data tersedia ketika dibutuhkan dan data tersebut akurat dan dapat dipercaya.

Penjualan merupakan salah satu aktifitas yang menjadi prioritas utama dari perusahaan yang bergerak di perdagangan, baru kemudian ditunjang oleh aktifitas-aktifitas lain seperti pengendalian piutang dan penerimaan pembayaran. Berdasarkan hal tersebut, semua aktifitas penjualan yang melibatkan data dan informasi tentang siapa yang menjual dan siapa yang membeli, barang apa yang terjual, jumlah terjual, harga terjual, kemana barang harus dikirim serta data-data yang menyangkut pembayaran perlu dicatat dengan baik dan benar serta rinci dalam SIA.

Selain hal-hal yang terkait dengan pendapatan dari penjualan, SIA pun perlu mencatat datadata yang mengurangi pendapatan, seperti retur penjualan. Retur penjualan menjadi hal yang cukup krusial karena dapat merusak citra bisnis dari perusahaan. Oleh sebab itu, sebuah SIA perlu mencatat hal tersebut dan menghasilkan informasi untuk manajer, agar manajer dapat mempelajari hal-hal yang menjadi alasan kenapa retur penjualan tersebut terjadi. Walaupun retur penjualan tidak dapat dihilangkan, kebijakan-kebijakan untuk menekan serendah mungkin terjadinya proses retur diharapkan untuk kedepannya dapat dilakukan dengan mempelajari penyebab-penyebabnya. Seperti yang dikatakan oleh Hall (2008), pelanggan mengembalikan barang dagangan yang telah mereka beli karena beberapa alasan, antara lain penjual mengirimkan barang dagang yang salah; barang tersebut cacat; produk rusak dalam pengiriman; penjual melakukan pengiriman barang terlambat atau tertunda dalam perjalanan, dan pembeli menolak pengiriman tersebut.

Pada era persaingan yang demikian ketat dan daya beli masyarakat yang kurang begitu baik, aktifitas penjualan tidak akan lepas dari piutang. Karena piutang adalah uang yang terhutang oleh konsumen atas barang yang telah dijual atau jasa yang diberikan kepadanya. Piutang menunjukkan kredit konsumen dan informasi mengenai pembayaran yang telah dilakukan dan bermanfaat bagi administrasi kebijakan kredit perusahaan secara keseluruhan (Bodnar dan Hopwood, 2004, p. 272). Piutang-piutang tersebut pada akhirnya akan ditagihan dan akan menjadi kas atau setara dengan kas.

Perlu dipahami, bahwa kas tidaklah selalu berbentuk uang tunai. Kas yang dimaksud disini bisa berupa uang tunai sendiri, rekening giro, cek ataupun deposito di bank. Seperti yang disampaikan oleh Weygandt, et al. (2005, p. 326), "Kas adalah aset yang paling mudah untuk dialihkan dan digunakan, dimana kas terdiri dari uang koin, uang kertas, cek, uang dipesan, dan uang di-tangan atau deposit di suatu bank atau jenis deposit lainnya.”

Dari uraian diatas, dapatlah dilihat bahwa peran sistem informasi akuntasi dalam siklus pendapatan merupakan sebuah sistem informasi untuk melakukan kegiatan administrasi dimana didalamnya terkandung pengendalian internal agar semua atifitas dapat dilaporan secara wajar, transparant dan akunable. Mengacu pada Bodnar dan Hopwood (2004, p. 265-268) fungsi yang terkait dalam siklus pendapatan meliputi: (1)Fungsi penjualan; (2)Fungsi dalam menerima pesanan pelanggan, meminta otorisasi kredit, mengisi faktur penjualan tunai, serta menentukan tanggal dan tujuan pengiriman; (3)Fungsi kredit; (4)Fungsi peneliti status kredit pelanggan dan pemberi otorisasi kredit kepada pelanggan; (5)Fungsi gudang; (6)Fungsi penyimpan dan penyiapan barang yang dipesan 
pelanggan; (7)Fungsi pengiriman; (8)Fungsi dalam penyerahan barang atas dasar surat pesanan penjualan yang diterima dari fungsi penjualan; (9)Fungsi penagihan; (10)Fungsi dalam verifikasi pesanan berdasarkan dokumen-dokumen pesanan yang diterima, kemudian membuat dan mengirimkan faktur kepada pelanggan; (11)Fungsi akuntansi; (12)Fungsi pencatat transaksi penjualan, piutang, serta penerimaan kas secara periodik; (13)Fungsi kas; (14)Fungsi penanggung jawab sebagai penerima kas dari hasil penjualan untuk diteruskan ke bank; (15)Fungsi pemeriksa atau audit intern; (16)Fungsi penanggung jawab dalam melaksanakan penghitungan kas yang ada di tangan fungsi kas secara periodik, serta dalam melakukan rekonsiliasi bank untuk mengecek ketelitian catatan kas yang diselenggarakan oleh fungsi akuntansi.

\section{HASIL DAN PEMBAHASAN}

\section{Proses Bisnis Sistem Berjalan}

Berdasarkan pengamatan aktifitas siklus pendapatan PT. Surya Warfa Kharisma dan wawancara dengan orang-orang yang terlibat, dihasilkan proses bisnis yang sedang berjalan (Gambar 1) dimana siklus pendapatan yang dibahas disini berupa penjualan, piutang dan retur penjualan.

Prosedur penjualan diawali ketika bagian administrasi menerima permintaan penawaran harga dari klien atau calon pelanggan. Berdasarkan permintaan penawaran harga dari pelanggan, bagian administrasi menghubungi bagian perbekalan untuk mengecek ketersediaan barang serta jumlah yang diminta melalui telepon. Jika barang dan jumlah yang diinginkan pelanggan tersedia, bagian administrasi membuat Surat Penawaran Harga yang didasarkan atas daftar harga barang Standar yang dimiliki arsip administrasi.

Setelah terjadi kesepakatan harga, pelanggan akan mengirimkan Surat Pemesanan Barang atau Purchase Order (PO) kepada perusahaan. Berdasarkan PO yang diterima, bagian administrasi membuat Sales Contract antara dua pihak yang melampirkan kesepakatan harga, serta mencantumkan cara pembayaran, dan jangka waktu pembayaran.

Bagian administrasi membuat Delivery Order (DO) sebanyak 3 rangkap, kemudian diserahkan ke bagian keuangan. Berdasarkan Sales Contract dan DO yang diterima, bagian keuangan mencatat pesanan pelanggan tersebut ke dalam invoice.

Berdasarkan DO, bagian perbekalan mencatat pengeluaran barang pada buku persediaan. Pada saat penyerahan barang, bagian perbekalan melampirkan invoice dan DO untuk ditandatangani pelanggan.

Setelah pengiriman barang selesai, Bagian keuangan mencocokkan DO yang telah ditandatangani pelanggan dengan Sales Contract serta invoice yang ada di arsip sementara. Selanjutnya, bagian keuangan mencatat transaksi penjualan ke dalam jurnal penjualan dan menambahkan piutang pelanggan apabila penjualan dilakukan secara kredit.

Pelanggan dapat melakukan klaim terhadap barang yang rusak atau kondisi lain yang tidak sesuai dengan pesanan dengan jangka waktu pengembalian berbeda-beda tergantung kesepakatan yang tertera dalam perjanjian. Dalam hal ini, pelanggan harus melampirkan barang yang diretur dengan invoice serta DO yang diterima ketika pengiriman barang. 


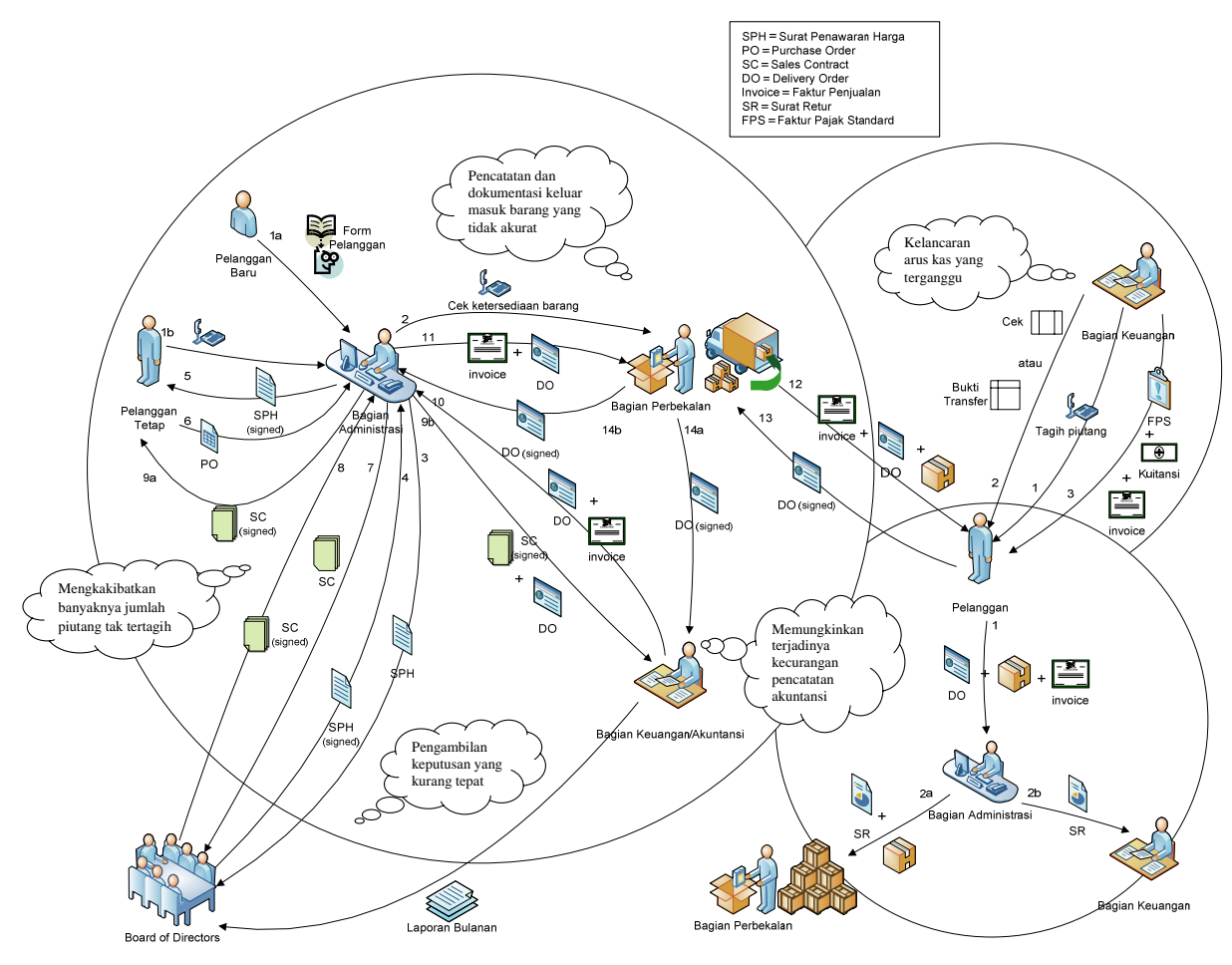

Gambar 1. Proses bisnis SIA penjulan, piutang, dan penerimaan kas yang berjalan.

Apabila keluhan yang ada sesuai dengan kebijakan retur perusahaan, maka bagian administrasi akan mencatatnya ke dalam Surat Retur (SR).

Berdasarkan retur yang terjadi, bagian perbekalan menerima barang retur dan melakukan pencatatan ke dalam buku persediaan. Sedangkan SR yang diterima bagian keuangan dicocokkan dengan invoice yang diarsip sementara oleh bagian keuangan untuk digunakan sebagai dasar pencatatan retur penjualan dan pengurangan piutang pelanggan. Barang yang diretur dapat dikembalikan tanpa penukaran atau dengan penukaran barang sejenis. Apabila atas permintaan pelanggan yang menginginkan bahwa barang yang diretur agar ditukarkan dengan barang pengganti dengan jenis dan tipe barang yang sama, bagian administrasi membuat Delivery Order-Retur (DORetur) sebanyak 3 rangkap. Surat DO-Retur diserahkan kepada bagian perbekalan untuk selanjutnya akan dilakukan pengiriman barang seperti prosedur pengiriman standar.

Secara berkala, bagian keuangan akan memeriksa invoice untuk mengetahui piutang pelanggan yang jatuh tempo. Atas piutang yang telah jatuh tempo, bagian keuangan menghubungi pelanggan dan melakukan penagihan.

Dengan adanya konfirmasi pembayaran dari pelanggan, bagian keuangan membuat Faktur Pajak Standar (FPS) dan kuitansi yang kemudian akan diserahkan kepada pelanggan sebagai bukti pembayaran yang lengkap dan sudah lunas.

Setelah menerima pembayaran, bagian keuangan mencatat penerimaan kas ke dalam jurnal penerimaan kas dan mengurangi piutang pelanggan. Kemudian pada akhir bulan, bagian keuangan akan membuat laporan penjualan dan laporan penerimaan kas yang ditujukan kepada Direktur sebagai pelaporan bulanan dan bahan evaluasi. 


\section{Analisis kebutuhan Informasi}

Berdasarkan hasil analisis SIA penjualan, piutang, dan penerimaan kas berjalan, ditemukan beberapa masalah yang mengganggu kegiatan perusahaan dan akan berpengaruh terhadap perkembangan perusahaan. Masalah yang dihadapi perusahaan saat ini dapat dijelaskan pada tabel 1 berikut ini:

Tabel 1

Analisis Kebutuhan Informasi

\begin{tabular}{|c|c|c|c|}
\hline Sasaran & Masalah & Solusi & Kebutuhan Informasi \\
\hline $\begin{array}{l}\text { Pengelolaan arus kas yang } \\
\text { lancar untuk membiayai } \\
\text { kegiatan operasional } \\
\text { perusahaan }\end{array}$ & $\begin{array}{l}\text { Terjadinya penumpukan } \\
\text { piutang sehingga } \\
\text { mengganggu arus kas } \\
\text { perusahaan. }\end{array}$ & $\begin{array}{l}\text { Menerapkan kreteria } \\
\text { limit kredit }\end{array}$ & $\begin{array}{ll}\text { - } & \text { Analisis Umur Piutang } \\
\text { - } & \text { Penjualan Berdasarkan Pelanggan } \\
\text { - } & \text { Pembayaran berdasarkan } \\
& \text { Pelanggam }\end{array}$ \\
\hline $\begin{array}{l}\text { Meningkatkan kepercayaan } \\
\text { pelanggan }\end{array}$ & $\begin{array}{l}\text { Jumlah retur dan } \\
\text { komplain pelanggan } \\
\text { yang tinggi }\end{array}$ & $\begin{array}{l}\text { Menjamin mutu } \\
\text { barang dan } \\
\text { meningkatkan mutu } \\
\text { kerja. }\end{array}$ & $\begin{array}{ll}\text { - } & \text { Penjualan Perbarang } \\
\text { - } & \text { Retur Penjualan } \\
\text { - } & \text { Rugi Laba }\end{array}$ \\
\hline
\end{tabular}

Atas kebutuhan informasi terhadap permasalahan yang terjadi, dan kebutuhan informasi, maka dirancang SIA yang dirancang sesuai dengan kebutuhan organisasi seperti gambar 2 berikut.

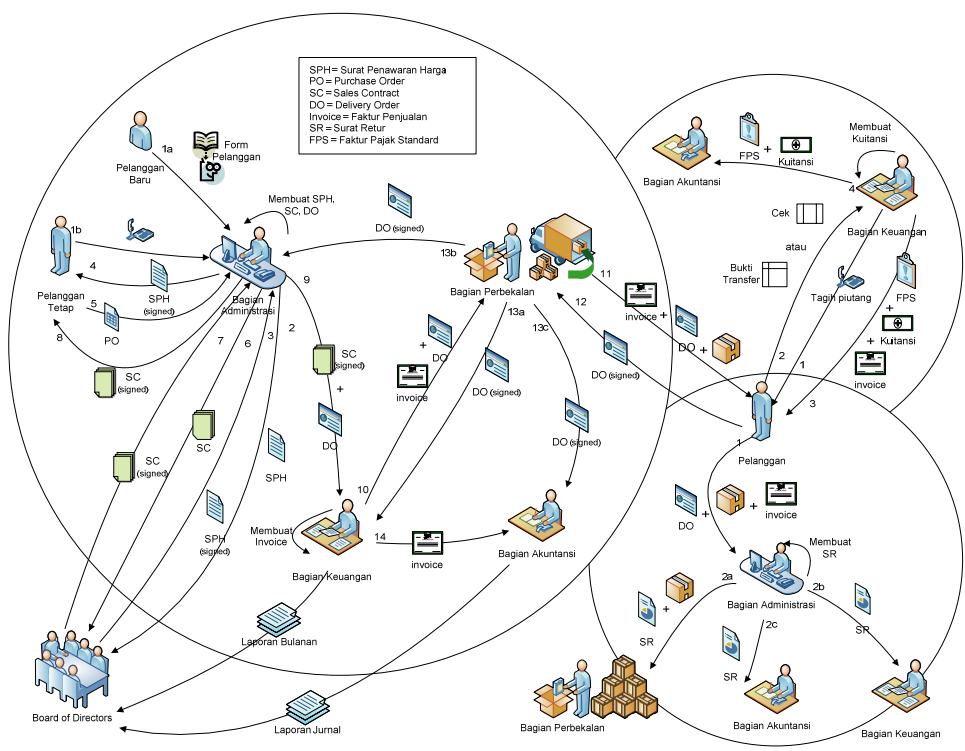

Gambar 2. Proses bisnis SIA penjulan, piutang, dan penerimaan kas yang diusulkan.

\section{Perancangan SIA Penjulan, Piutang, dan Penerimaan Kas yang Diusulkan}

Prosedur yang diusulkan terhadap SIA penjualan, piutang dan penerimaan kas PT. Surya Warfa Kharisma tidaklah mengalami banyak perubahan (Gambar 2).

\section{Prosedur Penjualan diusulkan:}

Kegiatan penjualan berawal ketika bagian administrasi menerima permintaan penawaran harga dari klien atau calon pelanggan, baik yang datang langsung, melalui telepon atau fax. Bagian 
administrasi melakukan pengecekan terhadap status pelanggan, apabila pelanggan baru maka bagian administrasi perlu mendata pelanggan dan mencatatnya ke dalam database pelanggan untuk disimpan sebagai arsip.

Jika barang dan jumlah yang diinginkan pelanggan tersedia, maka bagian administrasi membuat Surat Penawaran Harga (SPH) yang didasarkan atas daftar harga barang standar yang ada di database barang. Setelah diotorisasi direktur, bagian administrasi mendistribusikan SPH sebagai berikut: SPH rangkap 1 dikirimkan kepada pelanggan; SPH rangkap 2 untuk arsip bagian administrasi.

Dalam melakukan kesepakatan harga, biasanya calon pembeli akan melakukan penawaran harga. Pelanggan menghubungi perusahaan, untuk melakukan negosiasi harga yang telah diberikan perusahaan. Setelah terjadi kesepakatan harga, pelanggan akan mengirimkan Surat Pemesanan Barang atau Purchase Order (PO) kepada perusahaan yang menyatakan bahwa pelanggan setuju untuk membeli sejumlah barang tertentu dengan harga yang telah disepakati. Berdasarkan PO yang diterima, bagian administrasi membuat Sales Contract antara dua pihak yang melampirkan kesepakatan harga, serta mencantumkan cara pembayaran, jangka waktu pembayaran dan jangka waktu penyerahan barang.

Pada saat pembuatan Sales Contract, sistem melakukan pengecekan limit kredit pelanggan yang tersedia. Apabila kredit tersedia tidak memenuhi untuk dilakukan transaksi, sistem akan menolak untuk memproses Sales Contract dan memerlukan otorisasi direktur dalam melanjutkan transaksi. Direktur juga dapat mengubah limit kredit pelanggan agar transaksi dapat dilanjutkan.

Setelah meminta otorisasi direktur, Sales Contract dikirimkan kepada pelanggan. Distribusi dokumen yang dibuat sebanyak 3 rangkap ini adalah sebagai berikut: Sales Contract rangkap 1 untuk pelanggan; Sales Contract rangkap 2 untuk bagian keuangan; Sales Contract rangkap 3 untuk arsip bagian administrasi.

Selanjutnya bagian administrasi membuat Delivery Order (DO) sebanyak 4 rangkap yang kemudian diserahkan ke bagian keuangan. Berdasarkan Sales Contract dan Delivery Order yang diterima, bagian keuangan mencatat pesanan pelanggan tersebut ke dalam invoice sebanyak 4 rangkap yang akan didistribusikan sebagai berikut: invoice rangkap 1 untuk pelanggan (setelah melakukan pembayaran); invoice rangkap 2 diserahkan kepada pelanggan bersamaan dengan pengiriman barang; invoice rangkap 3 untuk arsip bagian keuangan; invoice rangkap 4 untuk bagian akuntansi.

Jika transaksi dilakukan secara kredit, invoice rangkap 1 akan diarsip ke dalam arsip sementara oleh bagian keuangan. Sedangkan untuk transaksi penjualan tunai, invoice rangkap 1 diserahkan bersamaan dengan invoice rangkap 2 dan barang pada saat pengiriman barang.

Bagian keuangan meneruskan DO sebanyak 4 rangkap dan invoice rangkap 2 (beserta invoice rangkap 1 jika transaksi penjualan secara tunai) kepada bagian perbekalan. Surat DOini merupakan pernyataan yang digunakan sebagai perintah pengeluran barang dari gudang. Berdasarkan DO, bagian perbekalan mencatat pengeluaran barang pada database persediaan. Dengan demikian, barang pun telah siap untuk dikirimkan kepada pelanggan.

Pada saat penyerahan barang, bagian perbekalan melampirkan invoice rangkap 2 (beserta invoice rangkap 1 jika transaksi penjualan secara tunai) dan DO 4 rangkap untuk ditandatangani pelanggan. Invoice rangkap 2 (beserta invoice rangkap 1 jika transaksi penjualan secara tunai) dan DO rangkap 1 diserahkan kepada pelanggan sebagai bukti bahwa barang yang dikirim telah diterima oleh pelanggan. DO rangkap 1 untuk pelanggan; DO rangkap 2 untuk bagian keuangan; DO rangkap 3 untuk arsip bagian administrasi; DO rangkap 4 untuk bagian perbekalan.

Setelah pengiriman barang selesai, bagian pengiriman mendistribusikan DO rangkap 2 yang telah ditandatangani pelanggan kepada bagian keuangan sebagai laporan pengiriman barang. 
Sedangkan DO rangkap 3 dikembalikan pada bagian administrasi dan mengarsip DO rangkap 4 sebagai bukti tertulis pengeluaran barang.

Bagian keuangan mencocokkan DO rangkap 2 yang telah ditandatangani pelanggan dengan invoice rangkap 3 yang ada di arsip sementara. Berdasarkan invoice rangkap 4 yang diterima, bagian akuntansi mencatat transaksi penjualan ke dalam jurnal penjualan dan sistem menambahkan piutang pelanggan apabila penjualan dilakukan secara kredit. Kemudian dokumen-dokumen tersebut diarsipkan berdasarkan tanggal.

\section{Prosedur Retur Penjualan}

Pelanggan dapat melakukan klaim terhadap barang yang rusak atau kondisi lain yang tidak sesuai dengan pesanan. Jangka waktu pengembalian berbeda-beda tergantung kesepakatan yang tertera dalam perjanjian dengan masing-masing pelanggan. Dalam hal ini, pelanggan harus melampirkan barang yang diretur dengan invoice serta DO rangkap 1 yang diterima ketika pengiriman barang.

Bagian administrasi menangani keluhan pelanggan, dan menghubungi bagian perbekalan untuk memeriksa kondisi barang. Apabila keluhan yang ada sesuai dengan kebijakan retur perusahaan, maka bagian administrasi akan mencatatnya ke dalam Surat Retur (SR) sebanyak 4 rangkap sebagai berikut: SR rangkap 1 untuk pelanggan; SR rangkap 2 untuk bagian akuntansi; SR rangkap 3 untuk bagian perbekalan; SR rangkap 4 untuk arsip bagian administrasi. Berdasarkan retur yang terjadi, bagian perbekalan menerima barang retur. Sedangkan SR rangkap 2 yang diterima bagian akuntansi dicocokkan dengan invoice rangkap 4 yang ada diarsip. Surat Retur ini digunakan sebagai dasar pencatatan retur penjualan dan pengurangan piutang pelanggan.

Barang yang diretur dapat dikembalikan tanpa penukaran atau dengan penukaran barang sejenis. Apabila atas permintaan pelanggan yang menginginkan bahwa barang yang diretur agar ditukarkan dengan barang pengganti dengan jenis dan tipe barang yang sama, bagian administrasi membuat Delivery Order-Retur (DO-Retur) sebanyak 4 rangkap. Surat DO-Retur diserahkan kepada bagian perbekalan untuk selanjutnya akan dilakukan pengiriman barang seperti prosedur pengiriman standar. Berdasarkan DO-Retur ini, bagian perbekalan menyiapkan sejumlah barang yang dibutuhkan kemudian kembali melakukan pengiriman barang kepada pelanggan dan melampirkan DO-Retur untuk ditandatangani pelanggan. Setelah pengiriman barang retur selesai, bagian perbekalan mendistribusikan DO-Retur yang telah ditandatangani pelanggan sebagai berikut: DO-Retur rangkap 1 untuk pelanggan; DO-Retur rangkap 2 untuk bagian keuangan; DO-Retur rangkap 3 untuk arsip bagian administrasi; DO-Retur rangkap 4 untuk bagian perbekalan.

\section{Prosedur Penerimaan Pembayaran dari Pelanggan}

Secara berkala, bagian keuangan akan memeriksa Daftar Piutang untuk mengetahui invoice yang segera jatuh tempo. Bila terdapat piutang telah jatuh tempo telah dibayarkan pelanggan, bagian keuangan menghubungi pelanggan dan melakukan penagihan. Dengan adanya konfirmasi pembayaran dari pelanggan, bagian keuangan membuat Faktur Pajak Standar (FPS) sebanyak 3 rangkap dan Kuitansi sebanyak 3 rangkap kemudian meminta otorisasi direktur. Pelanggan yang melakukan pembayaran dengan cara transfer, harus menyerahkan bukti transfer kepada perusahaan. Sedangkan jika pembayaran dilakukan dengan cek atau giro, bagian keuangan harus memastikan kepada pelanggan dan bank yang bersangkutan bahwa cek atau giro tersebut dapat dicairkan pada tanggal jatuh tempo.

Ketika melakukan pembayaran, pelanggan menandatangani FPS dan kuitansi yang masingmasing berangkap 3. Bagian keuangan juga melampirkan invoice rangkap 1 kepada pelanggan, kemudian menyerahkannya beserta FPS rangkap 1 dan Kuitansi rangkap 1 yang telah ditandatangani kepada pelanggan. Dokumen-dokumen yang diterima pelanggan berikut ini merupakan bukti 
pembayaran yang lengkap dan sudah lunas: FPS rangkap 1 untuk pelanggan; FPS rangkap 2 untuk diarsip bagian keuangan; FPS rangkap 3 untuk bagian akuntansi; Kuitansi rangkap 1 untuk pelanggan; Kuitansi rangkap 2 untuk arsip bagian keuangan; Kuitansi rangkap 3 untuk bagian akuntansi.

Sedangkan untuk transaksi penjualan tunai, FPS sebanyak 2 rangkap dan kuitansi 2 rangkap yang dibuat bagian keuangan akan didistribusikan kepada bagian perbekalan untuk dilampirkan pada saat pengiriman barang beserta invoice dan DO. Bagian perbekalan menerima pembayaran dari pelanggan, kemudian memberikan FPS rangkap 1 dan Kuitansi rangkap 1 yang sudah dicap lunas kepada pelanggan. Untuk FPS rangkap 2 dan kuitansi rangkap 2 yang telah ditandatangani pelanggan, dikembalikan ke bagian keuangan untuk diarsip.

Berdasarkan FPS rangkap 3 dan kuitansi rangkap 3 yang diterima, bagian akuntansi mencatat penerimaan kas ke dalam jurnal penerimaan kas dan mengurangi piutang pelanggan. Kemudian rangkap FPS dan rangkap kuitansi akan diarsip permanen berdasarkan tanggal. Secara berkala, manajer keuangan akan melakukan penilaian pelanggan agar sistem dapat meng-update nilai kredibilitas pelanggan. Bagi pelanggan baru, penilaian ini tidak berlaku karena belum ada data historis pembelian yang dilakukan pelanggan. Untuk menghindari pemberian kredit yang tidak potensial, pelanggan baru diwajibkan melakukan transaksi secara tunai saja.

Penilaian pelanggan ini dapat dilakukan ketika sudah terdapat data historis transaksi penjualan (lima transaksi pertama atau 6 bulan sejak pelanggan didaftarkan). Penetapan kriteria yang dipakai ditentukan berdasarkan kebijakan manajemen perusahaan dan kriteria 5 C (Character, Capacity, Capital, Collateral, dan Condition), dimana pengukurannya menggunakan data historis penjualan per bulan, pembayaran pelanggan, jumlah retur penjualan pelanggan, dan lama langganan. Tabel 2 berikut ini menunjukkan pengukuran kriteria dimaksud.

Tabel 2

Kriteria Penetapan Limit Kredit Pelanggan

\begin{tabular}{lcccccc}
\hline \multicolumn{1}{c}{ Kriteria } & Grade A & Grade B & Grade C & Grade D & Grade E & Bobot \\
\hline Nilai transaksi per bulan & $>80$ juta & $60-80$ juta & $40-60$ juta & $20-40$ juta & 0 -20 juta & 40 \\
\hline Ketepatan membayar & $1-30$ hari & $31-60$ hari & $61-90$ hari & $91-120$ hari & $>120$ hari & 30 \\
\hline Jumlah retur per bulan & $0 \%$ & $1-5 \%$ & $6-10 \%$ & $10-14 \%$ & $>14 \%$ & 15 \\
\hline Lama langganan & $>8$ tahun & $6-8$ tahun & $4-6$ tahun & $2-4$ tahun & $0-2$ tahun & 15 \\
\hline
\end{tabular}

Pertama-tama pelanggan dikategorikan ke beberapa grade, yaitu Grade A yang memiliki 5 poin, Grade B dengan 4 poin, Grade C dengan 3 poin, Grade D dengan 2 poin, dan Grade E dengan 1 poin. Kemudian poin atas grade dikalikan dengan bobot masing-masing kriteria yang menghasilkan range nilai dengan jumlah limit kredit disarankan sebagai berikut: $100-200$ poin = limit kredit disarankan Rp. 20.000.000; $201-300$ poin = limit kredit disarankan Rp. 50.000.000; $301-400$ poin = limit kredit disarankan Rp. 70.000.000; $401-500$ poin = limit kredit disarankan Rp. 100.000.000.

Dari uraian proses bisnis diatas, maka dapat digambarkan user requirement dari SIA penjulan, piutang, dan penerimaan kas yang dikembangkan. User requirement tersebut digambarkan dalam bentuk Use Case Diagram (Gambar 3). Dimana dalam SIA yang dirancang ini terdapat 4 actor dan 23 Use Case yang diantaranya saling ketergantungan. 


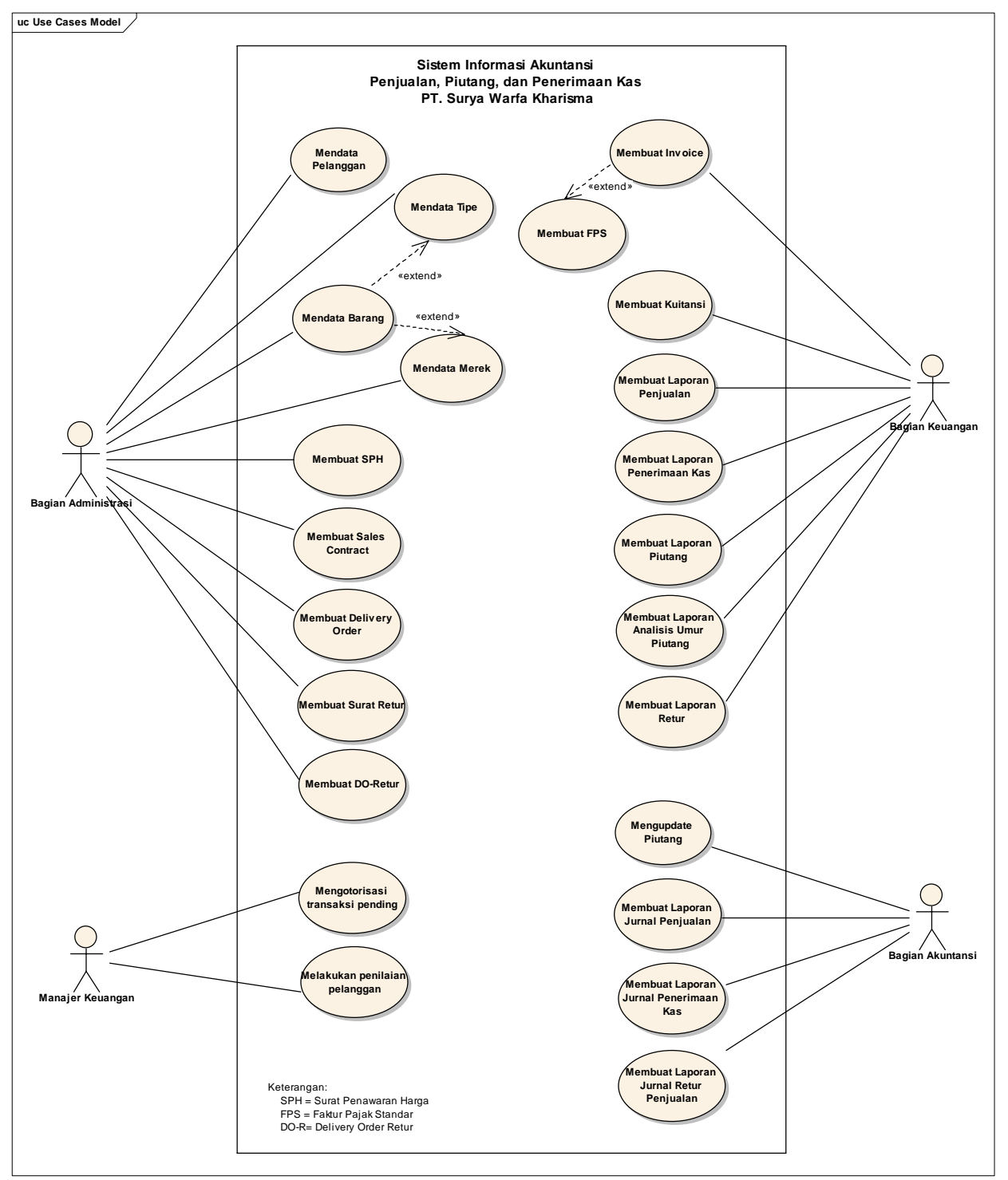

Gambar 3. Use Case Diagram dari SIA penjualan, piutang, dan penerimaan kas PT. Surya Warfa Kharisma.

Di dalam proses yang terdapat dalam use case tersebut terdapat beberapa object beserta atribut dan fungsi-fungsinya. Beberapa Object tersebut menggambarkan model dari SIA yang dirancang. Adapun object yang terkait dalam SIA penjulan, piutang, dan penerimaan kas digambarkan menjadi Model dari proses bisnis dengan menggunakan Class Diagram (Gambar 4). Model ini menggambarkan SIA penjualan, piutang, dan penerimaan kas terinegrasi, sehingga dapat menghasilkan informasi yang sesuai kebutuhan. Berdasarkan Gambar 4 diatas, dapat disusun kebutuhan user dan digambarkan dengan navigation diagram (Gambar 5).

\section{PENUTUP}

Dengan penerapan SIA yang sesuai dengan prosedure yang sudah ditentukan, kesalahan user (human error) seperti masalah pencatatan, khususnya pada bagian penjualan, piutang dan penerimaan kas dapat berkurang serta mampu memberikan informasi kepada manajer untuk mendukung tugasnya. Selain hal tersebut, SIA yang dikembangkan ini, akan secara otomatis memberikan peringatan kepada 
user dalam hal pemberian piutang. Untuk lebih sempurna, perusahan perlu mengintegrasikan modul lainnya dalam SIA Penjualan, Piutang, dan Penerimaan Kas yang dikembangkan ini demi mendukung kegiatan operasional yang meliputi subsistem pembelian, persediaan dan penerimaan kas ke dalam SIA Penjualan, Piutang, dan Penerimaan Kas.

\section{DAFTAR PUSTAKA}

Bodnar, G. H., \& Hopwood, W. S. (2004). Accounting Information System, (9th ed.). New Jersey: Prentice-Hall.

Hall, James A. (2008). Accounting Information System, (6th ed.). Boston: South-Western College Publishing.

Romney, M. B., \& Steinbart, P. J. (2006). Accounting Information System, (10th ed.). New Jersey: Pearson Prentice Hall.

\section{LAMPIRAN}

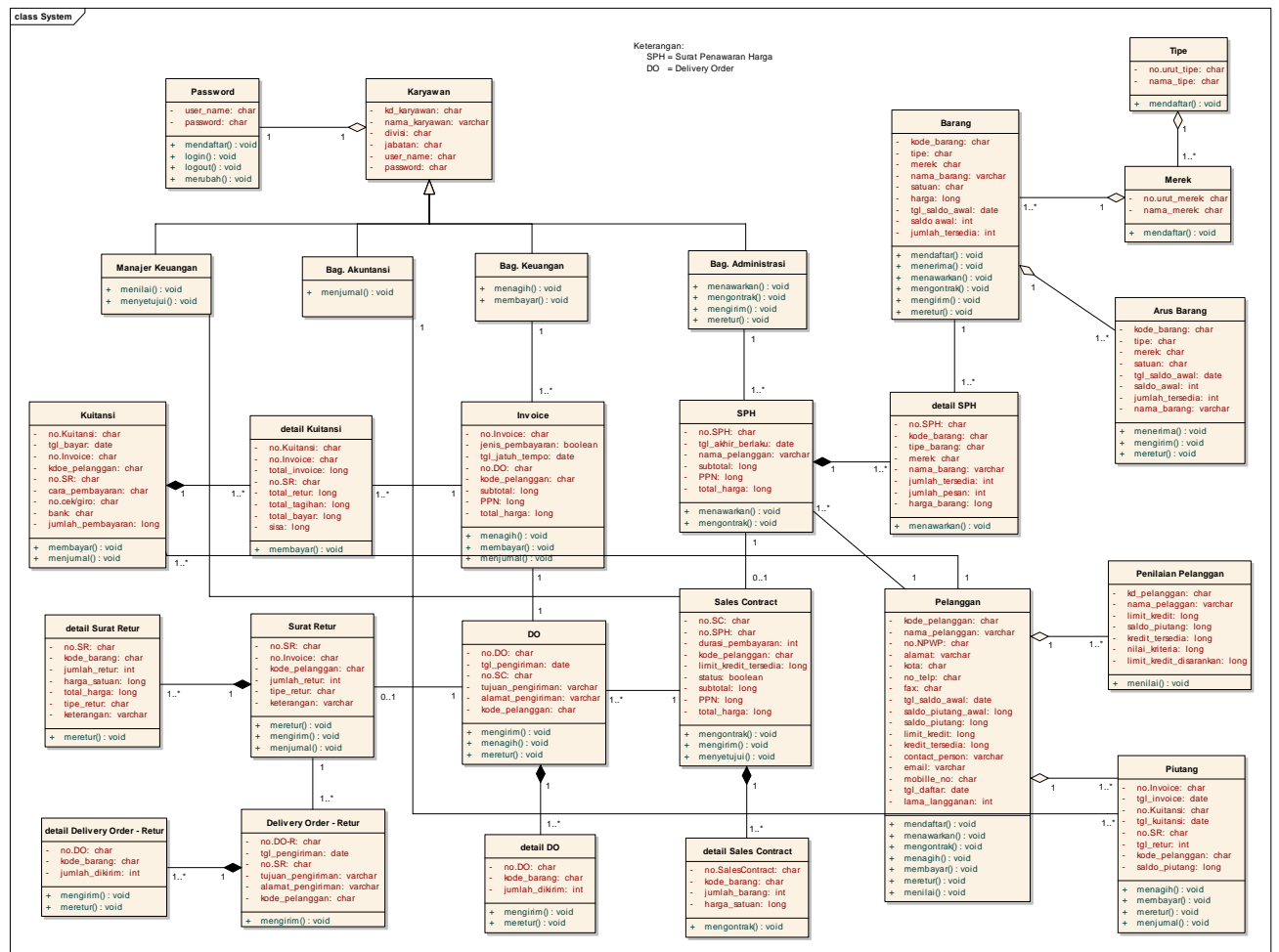

Gambar 4. Class Diagram SIA penjualan, piutang, dan penerimaan kas PT. Surya Warfa Kharisma. 


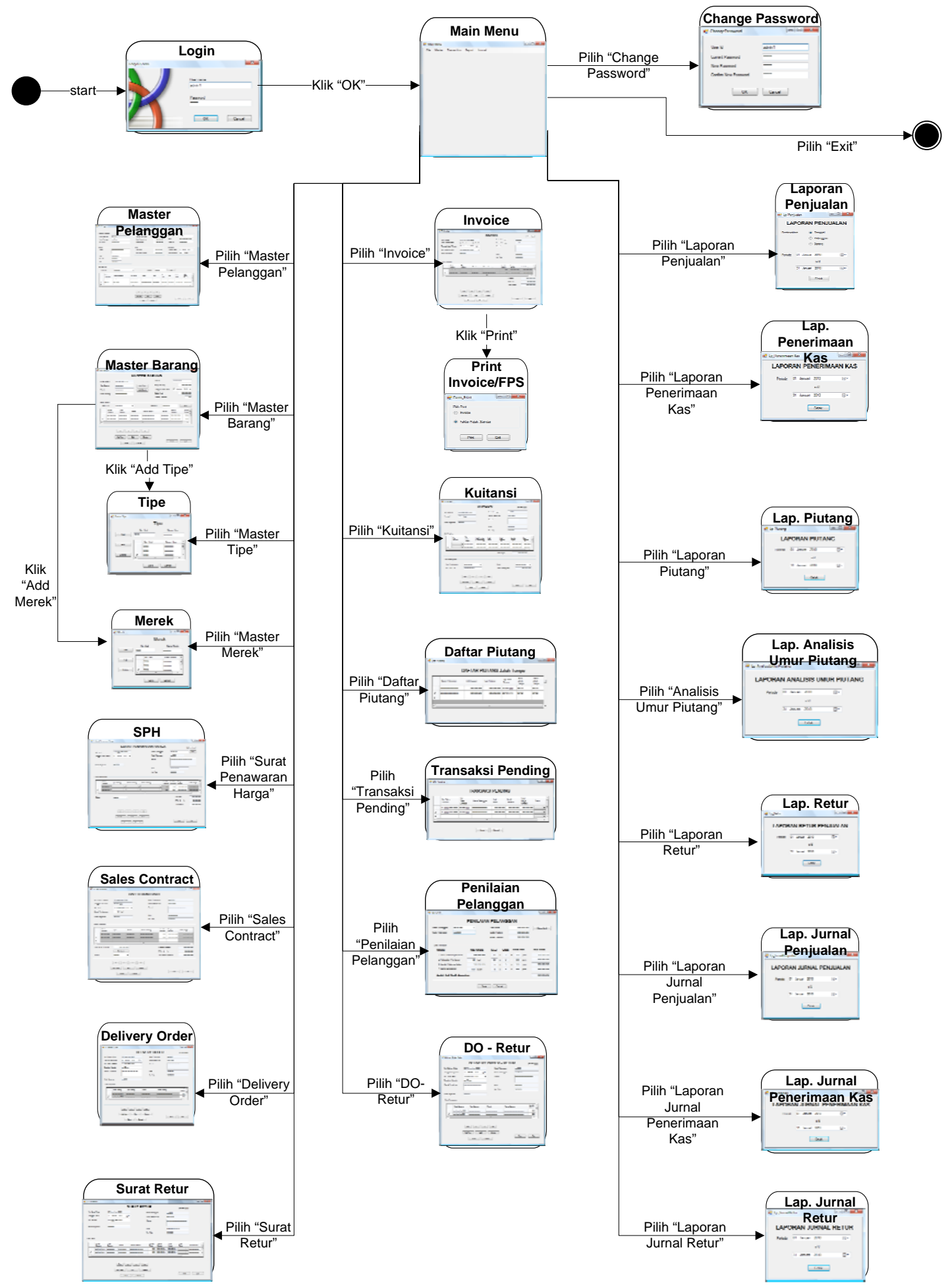

Gambar 5. Navigation Diagram SIA penjualan, piutang, dan penerimaan kas PT. Surya Warfa Kharisma. 